\title{
5-aminolevulinic Acid and Surgical Margin Analysis in Calvarial Metastasis with Pericranium or Dural Extension: Technical Note
}

\section{Ácido 5-aminolevulínico e análise da margem cirúrgica nas metástases da calvária com extensão de pericrânio ou dural: Nota Técnica}

\author{
Erasmo Barros da Silva Junior ${ }^{10}$ Joseph Franklin Chenisz da Silva ${ }^{10}$ Maurício Coelho Neto ${ }^{1}$ \\ Marcella Santos Cavalcanti ${ }^{2}$ Ricardo Ramina ${ }^{1}{ }^{10}$ \\ ${ }^{1}$ Departament of Neurosurgery, Instituto de Neurologia de Curitiba, \\ Curitiba, Paraná, Brazil \\ 2 Departament of Neuropathology, Instituto de Neurologia de \\ Curitiba, Curitiba, Paraná, Brazil

\begin{abstract}
Address for correspondence Erasmo Barros da Silva Júnior, MD, MSc, Instituto de Neurologia de Curitiba, Departament of Neurosurgery, Division of Neuro-oncology, Rua Jeremias Maciel Perretto, 300,
\end{abstract} \\ Curitiba, 81210-310, Brazil (e-mail: erasmo-inc@uol.com.br).
}

Arq Bras Neurocir 2020;39(3):207-212.

\begin{abstract}
Keywords

- 5-aminolevulinic acid

- calvarial metastases

- fluorescence surgery

- metastases

- skull metastases

- surgical margins
\end{abstract}

\section{Resumo}

Metastasis to the calvarium with direct pericranium or dural infiltration may be treated with radical surgical removal in selected cases. We describe microsurgical resection of calvarial metastases with fluorescence-guided technique using 5 -aminolevulinic acid (5-ALA) in two female patients with breast cancer. Fluorescence findings were positive in both cases. Margins in the scalp and dural layer were 5-ALA negative at the end of surgical removal. Intraoperative pathology was performed in all cases to confirm if oncological limits were free of disease. One case was 5-ALA positive in the outer layer of the dura-mater and another in the pericranium. At the end of the removal in both cases, the surgical margins were 5-ALA fluorescence-free. Intraoperative pathology confirmed oncological limits of the resection. 5-aminolevulinic acid fluorescence-guided surgery for calvarial metastases with pericranium and/or dural extension seems to be a safe and reliable method to aid the surgical margins for complete removal, possibly delaying or avoiding adjuvant irradiation for progression control.

Metástases da calvária com infiltração dural ou do pericrânio podem ser tratadas com remoção cirúrgica radical em casos selecionados. Descrevemos a ressecção microcirúrgica de metástases da calvária guiada por fluorescência usando ácido 5-aminolevulínico (5-ALA) em duas pacientes do sexo feminino com câncer de mama. Os achados da fluorescência foram positivos em ambos os casos. As margens nas camadas do couro cabeludo e dural foram negativas para 5-ALA ao final da remoção cirurgica. Patologia received

January 3, 2020

accepted

March 24, 2020
DOI https://doi.org/

10.1055/s-0040-1710312. ISSN 0103-5355.
Copyright $(2020$ by Thieme Revinter

Publicações Ltda, Rio de Janeiro, Brazil
License terms

(c) $(1) \$$ 
Palavras-chave

- ácido 5aminolevulinico

- metástases da calvária

- cirurgia por fluorescência

- metástases

- metástases cranianas

- margens cirúrgicas intraoperatória foi realizada em ambos os casos para confirmar os limites oncológicos. Um caso foi positivo para 5-ALA na camada externa da dura-máter e outra no pericrânio. No final da remoção, nos dois casos, as margens cirúrgicas foram 5-ALA negativas. A patologia intraoperatória confirmou as margens cirúrgicas livres. Cirurgia guiada por fluorescência com ácido 5-ALA para metástases da calvária com extensão para pericrânio e / ou dural parece ser um método seguro e confiável para auxiliar as margens cirúrgicas na remoção completa, possivelmente evitando ou retardando a irradiação adjuvante no controle da progressão.

\section{Introduction}

Skull metastases are a common condition in patients with disseminated bone metastatic disease. It may disseminate through blood, lymphatic transport or retrograde transport through the midline venous system. ${ }^{1}$ Metastases to the calvarium are the commonest cranial tumors in adults and have less impact in the cancer evolution than intraparenchymal metastatic lesions. ${ }^{2}$ They are often asymptomatic.

Early diagnosis of calvarial metastases is crucial for treatment success. The clinical presentation can be local pain or a palpable mass under the scalp. The disease was frequently underdiagnosed, often described in autopsies until the advances in imaging techniques increased the identification of previously asymptomatic lesions. ${ }^{2,3}$

Dural infiltration due to direct extension from calvarial metastasis is commonly observed, especially in patients with bone disease, and may account for $>60 \%$ of pachymeningeal metastasis cases. The disease may also extent to the scalp, the subdural space and the brain parenchyma in $\sim 34 \%$ of cases in some series. ${ }^{4}$ Proximity to dural sinuses, cranial nerves or eloquent cortex can cause severe neurological impairment, compromising treatment efficacy and survival prognosis., 5,

In patients with controlled systemic disease and Karnofsky performance status (KPS) $\geq 70 \%$, surgical management can be a safe treatment modality aiming total removal with oncological margins, ${ }^{4,6}$ possibly avoiding the necessity of local adjuvant irradiation.

5-aminolevulinic acid (5-ALA) fluorescence-guided surgery was first introduced in glioblastoma ${ }^{7}$ and has been a reliable standard for complete tumor removal and better progression free survival. The 5-ALA accumulated in the malignant lesion is converted to protoporphyrin IX (PpIX) and, under a blue filter illumination, shows a selective fluorescence, differing normal from infiltrated tissue with high sensitivity and specificity. ${ }^{8}$

About 40 to $62 \%$ of brain metastasis ${ }^{9-11}$ and 77 to $96 \%$ of intracranial meningiomas ${ }^{12}$ can also exhibit 5-ALA fluorescence, so its use may improve the extent of surgical resection. In these cases, there is a special focus in avoiding missed residual tumors, which can compromise local-recurrence rate and progression free survival. Although the benefits of 5-ALA fluorescence in meningioma surgery for the identifi- cation and removal of bone infiltration or hyperostosis has been described, ${ }^{13}$ there is few current data about its application for calvarial metastases with or without contiguous tissues (scalp and dura-mater) involvement. ${ }^{3}$

The present article aims to analyze the use of 5-ALA guided surgery in calvarial metastases with dural infiltration correlated with intraoperative pathology to improve the oncological safe margins to possibly reduce the risk of recurrence or the necessity of adjunct local treatment.

\section{Materials and Methods}

Between November 2015 and August 2019, 200 consecutive patients underwent 5-ALA fluorescence surgery in the Instituto de Neurologia de Curitiba, Curitiba, PR, Brazil. There were 25 patients with brain metastases and 2 patients with solitary metastatic tumor located in the calvarium without intraparenchymal disease. We retrospectively reviewed these two 5-ALA positive cases eligible for the study. Both cases were studied with magnetic resonance imaging (MRI) with aid of computed tomography (CT) scans to evaluate the extent of bone disease.

5-aminolevulinic acid is provided by Carbolution Chemicals (St. Ingbert, Germany). All of the patients signed an informed consent form, and the study was approved by the Institutional Ethical Review Board. The 5-ALA solution was orally administered at a dose of $20 \mathrm{mg} / \mathrm{kg} 3$ hours prior to the surgery. Patients care (anesthesia induction, positioning, etc.) were all performed as routine, including image-guidance with neuronavigation, although both cases showed a palpable mass below the scalp.

The Zeiss OPMI PENTERO 800 (Carl Zeiss, Oberkochen, Germany) with a special blue-light filter was used to identify 5-ALA-induced PpIX fluorescence and was graduated in strong, poor or negative. A curvilinear C-shape incision in the scalp was made around the mass, respecting the arterial pedicle, preserving the pericranium and incised circumferentially with a margin around the lesion. A single burr hole was performed, followed by the craniotomy. The specimen was removed with the galea and the inner table of the bone flap was inspected with the surgical microscope, first with the white and then with the blue light (-Fig. 1). The outer layer of the dura-mater in direct contact with the lesion was 

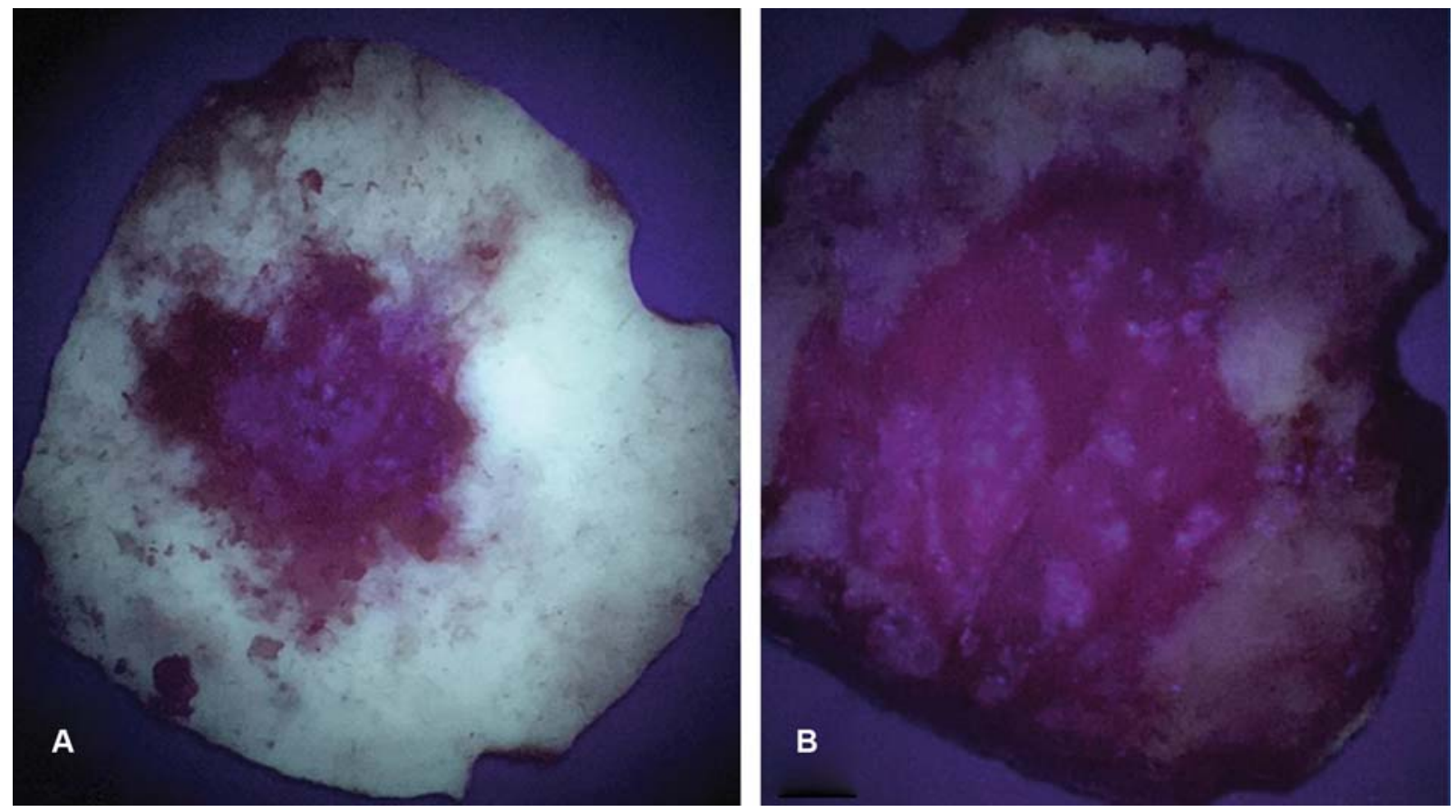

Fig. 1 Outer (a) and inner (b) table of calvarium inspected under blue light filter, showing lesion with a 5-ALA strong positiveness.

also inspected for 5-ALA graduation and was removed, avoiding entering the subdural space (-Fig. 2). Frozen section procedure was performed in the pericranium and dural margins to determine if tumoral tissue was present (-Fig. $\mathbf{3}$ ). After the resection, cranioplasty was performed and the skin was closed primarily. The entire specimen was inspected again under the microscope, to visualize the infiltration to the pericranium and the dura-mater.

Both patients studied retrospectively had diagnosis of solitaire metastatic calvarial lesion from breast cancer, age $<70$ years old, KPS of $90-100 \%$ and controlled systemic

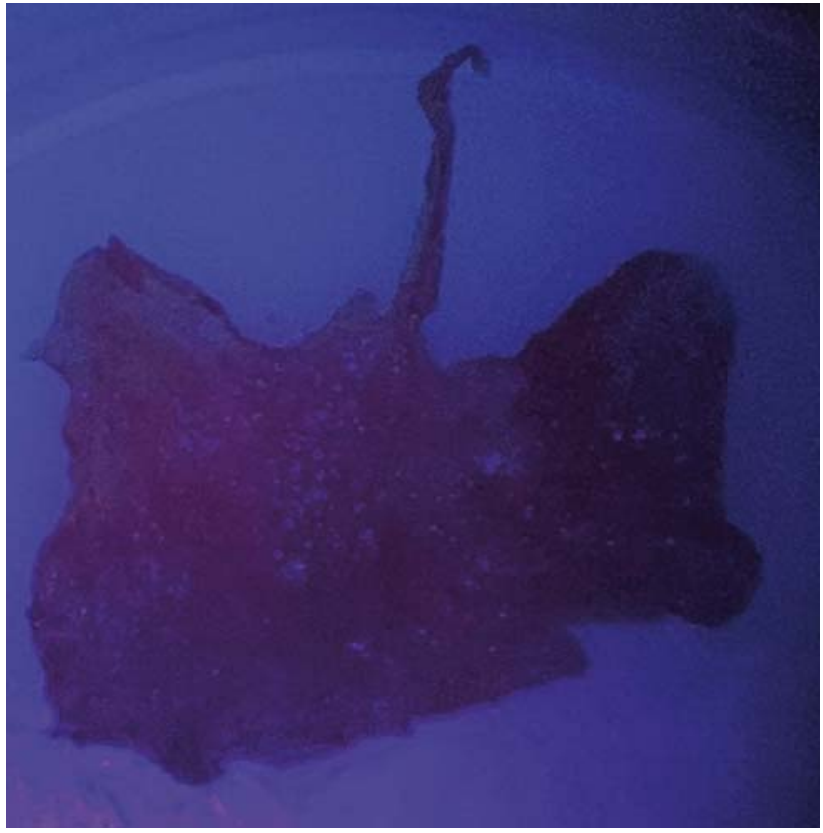

Fig. 2 Outer layer of dura-mater in direct contact with the mass inspected with the blue light filter, showing 5-ALA poor positiveness (a). disease with first line treatment. - Table 1 shows the characteristics and findings of each case.

\section{Results}

\section{Pericranium Findings}

In one case, the inner layer, in direct contact with the bone mass, was 5-ALA strong positive. The intraoperative pathology confirmed tumor infiltration. The other case was 5-ALA negative, also corroborated with the histopathological analysis.

\section{Bone Flap Findings}

Both specimens showed an intraosseous mass, removed en bloc. The outer and the inner table were 5-ALA strong in the tumor and the margins were visible even with white microscope light.

\section{Dural Findings}

In one case, the outer dural layer was 5-ALA poor positive. It was removed preserving the inner layer to avoid the subdural space. In the other case, the 5-ALA finding was negative. Both diagnoses were corroborated with intraoperative pathology.

There were no postoperative complications. Both patients had MRI scan 24 hours, 1 month, 3 month and 6 months after the surgery, without signs of local disease progression or KPS worsening until the end of the writing of the present article. No local adjuvant treatment was realized.

\section{Discussion}

Bone metastasis is a frequent complication of cancer and is especially higher among patients with more advanced disease, but the exact incidence of calvarial metastases remains 

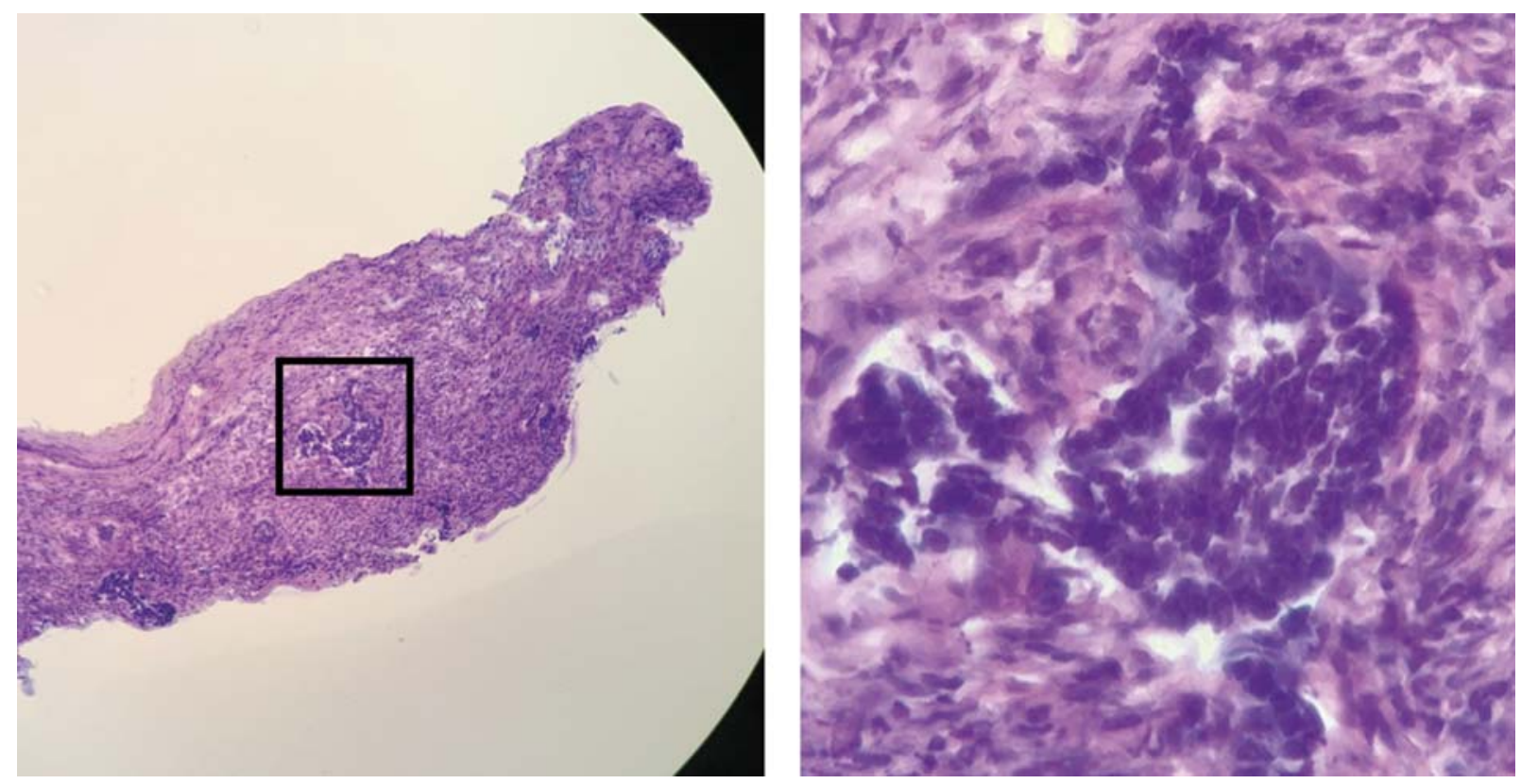

Fig. 3 Intraoperative pathology findings in 5-ALA positive outer dural margins, confirming tumor infiltration.

unknown. Dissemination may occur due to direct extension or by hematogenic pathway, with cancer cells adhering to the endosteal surface and invading the bone marrow. ${ }^{2,3,6}$

Breast, lung and prostate adenocarcinoma are the commonest primary lesions to metastasize to the skull due to a distinct bone tropism, but various other histologies have been reported. ${ }^{14,15}$ Mitsuya et al reported $55 \%$ of skull metastases from breast cancer in a series of 175 patients, with a preponderance female versus male of $7: 3$ patients. ${ }^{16}$ Once dissemination to the skull is diagnosed, the expected median survival rate is 20 months. In a retrospective study by Stark et al, ${ }^{2}$ there was an average period of 4 years between the initial primary cancer diagnosis and the detection of intraosseous metastasis.

While cranial nerves impairment is the commonest clinical presentation of skull base cancer, patients with calvarial circumscribed intraosseous metastasis can be completely asymptomatic. In cases of circumscribed invasive dural extension, $\sim 18 \%$ of the patients can present pain and brain swelling. Cranial metastases overlying or invading the dural venous sinuses can turn into symptomatic and predict worst outcomes. Frontal and parietal bones are the most common sites of calvarial metastases, often presenting a well-circumscribed asymptomatic mass under the scalp. ${ }^{4,5,16}$

In the diagnostic evaluation, the following aspects are particularly useful to be considered in the diagnosis: localization of the lesion in the calvary or in the skull base; local, multiple or diffuse bone distribution; and intraosseous invasion to the scalp or dura-mater. Computed tomography scanning may help the identification of calvarial metastases as lytic or sclerotic. Magnetic resonance imaging findings present hypointense signal in T1-weighted noncontrast sequence and often homogeneous gadolinium enhancement. Fat subtraction is important to determine tumor margins. ${ }^{4,6}$

Management of calvarial metastases may depend on symptomatology, patient KPS, relationship with dural sinuses and eloquent cortex, histopathology, extent of spread and scalp infiltration. ${ }^{3,5,6,16}$ Surgical treatment can be a safe palliative option for symptomatic patients, even when indicated after failed attempt with irradiation and/or chemotherapy.

In patients with a solitary metastatic mass, aggressive local treatment can sometimes result in prolonged survival. ${ }^{3,4}$

Table 1 5-aminolevulinic acid fluorescence and intraoperative pathology findings

\begin{tabular}{|l|l|l|l|l|l|l|}
\hline Patient & $\begin{array}{l}\text { Age } \\
\text { (years old)/ } \\
\text { Gender }\end{array}$ & Pathology & $\begin{array}{l}\text { Tumor } \\
\text { fluorescence }\end{array}$ & $\begin{array}{l}\text { Pericranium } \\
\text { fluorescence }\end{array}$ & $\begin{array}{l}\text { Dura-mater } \\
\text { fluorescence }\end{array}$ & $\begin{array}{l}\text { Intraoperative } \\
\text { pathology }\end{array}$ \\
\hline 1 & $33 \mathrm{~F}$ & $\begin{array}{l}\text { HER-2 negative, ER } \\
\text { and PR positive }\end{array}$ & Strong & Negative & $\begin{array}{l}\text { Outer layer: poor; } \\
\text { Internal layer: negative }\end{array}$ & $\begin{array}{l}\text { Pericranium negative; } \\
\text { Bone tumor and outer } \\
\text { dural layer positive; } \\
\text { internal dural layer } \\
\text { negative }\end{array}$ \\
\hline 2 & $40 \mathrm{~F}$ & $\begin{array}{l}\text { HER-2 negative, ER } \\
\text { positive PR negative }\end{array}$ & Strong & Strong & $\begin{array}{l}\text { Outer layer: negative; } \\
\text { Internal layer: negative }\end{array}$ & $\begin{array}{l}\text { Pericranium positive; } \\
\text { Bone tumor positive; } \\
\text { Dura-mater negative }\end{array}$ \\
\hline
\end{tabular}

Abbreviations: Her-2, human epidermal growth receptor 2; ER, estrogen receptor; PR, progesterone receptor. 
Although surgical resection may quickly relieve symptoms, it can be challenging and increase surgery morbidity, especially in patients with delayed diagnosis or uncontrolled systemic disease. The pericranium can also be directly infiltrated, and, in these cases, en bloc removal can be performed with scalp resection with the bone mass. ${ }^{6}$ Direct dural infiltration is related to higher local recurrence rates in cases of underlying sinus involvement due to the difficulties for complete resection. ${ }^{5}$ These cases also predict a more aggressive disease with worst neurological impairment and shorter survival. Irradiation is a treatment option alone, when surgery is contraindicated, or adjuvant to control tumor growth.

5-aminolevulinic acid is the metabolic precursor of hemoglobin that induces the synthesis of protoporphyrin IX (PpIX), a fluorescent compound in appropriately violet-blue filtered light. The PpIX stored in malignant lesions aids the differentiation between normal brain and tumor tissue with high sensitivity and specificity. 5-aminolevulinic acid-guided fluorescence was first introduced in malignant glioma surgery as an adjuvant tool for optimizing the removal of these tumors, $7,16,17$ leading to increased progression free survival. ${ }^{7,8,17}$ Over the years, its vibrant application has been introduced and studied in other intracranial neoplasms, such as brain $^{9-11}$ and spinal cord metastases ${ }^{18-20}$ and meningiomas. ${ }^{12,13,21}$

There is a 5-ALA positive fluorescence ranging from 77 to $96 \%$ of the intracranial meningiomas. The graduation in poor or strong may vary in the literature, but in an intratumoral homogenous fluorescence, it is observed in $>75 \%$ of the cases. There is no apparent correlation between histopathological findings and 5-ALA intraoperative fluorescence. ${ }^{13}$ The method can detect bone infiltration with $100 \%$ specificity and $89 \%$ sensitivity, ${ }^{21}$ confirming suspected invasion on preoperative evaluation. $^{12}$

More than $60 \%$ of intracranial metastases demonstrate a 5-ALA positive fluorescence, but it may range between 28 and $81.8 \%$ in large series. ${ }^{10}$ Adjacent brain tissue may be 5ALA positive without necessarily containing metastatic infiltration. $^{8}$ Furthermore, a heterogeneous positivity may be expected and even the previous administration of neoadjuvant chemotherapy can be a potential bias for fluorescence response. ${ }^{9,10}$

PpIV positive fluorescence is also related with a more benign behavior of brain metastases, while a negative fluorescence can be a more aggressive tumor with worse prognosis. ${ }^{9}$ Yang et $\mathrm{al}^{22}$ described the use of ALA for imaging and photodynamic targeting human epidermal growth receptor 2 (HER-2) positive tumors. Human epidermal growth receptor 2 is a driver oncogene with special importance in breast cancer classification, with sensitive ALA-mediated photodynamic therapy.

Both cases presented in our article were HER-2 positive and 5-ALA strong positive. We are routinely using 5-ALA fluorescence for intracranial gliomas and metastases since $2015,{ }^{18,19}$ and a primary diagnosis of breast cancer HER-2positive may support this method of intraoperative guidance. There is not any study about 5-ALA fluorescence surgery aiming complete removal of calvarial metastasis.
The management of these lesions can be controversial in the postoperative due to the decision about irradiation. Whole-brain radiotherapy is often elected in cases of diffuse calvarial involvement, while solitaire/oligometastatic disease supports local treatment. ${ }^{3,4,6}$ Modifications in the chemotherapy may also be needed at the time of diagnosis. With the free oncological margins in both cases, local adjuvant irradiation was not indicated. Patients continue to perform periodic MRI for evaluation.

\section{Conclusion}

5-aminolevulinic acid fluorescence surgery for calvarial metastases may provide a simple and reliable guide to determine the oncological limits with the pericranium and underlying dura-mater.

\section{Ethical Approval and Consent}

All procedures performed in studies involving human participants were in accordance with the ethical standards of the institutional research committee (CEP - Comitê de Ética em Pesquisa - Instituto de Neurologia de Curitiba) and with the 1964 Helsinki declaration and its later amendments or comparable ethical standards. Informed consent was obtained from both individual participants included in the present study.

Conflict of Interests

The authors have no conflict of interests to declare.

\section{References}

1 Coleman RE. Skeletal complications of malignancy. Cancer 1997; 80(8, Suppl)1588-1594

2 Stark AM, Eichmann T, Mehdorn HM. Skull metastases: clinical features, differential diagnosis, and review of the literature. Surg Neurol 2003;60(03):219-225, discussion 225-226

3 Wecht DA, Sawaya R. Lesions of the calvaria: surgical experience with 42 patients. Ann Surg Oncol 1997;4(01):28-36

4 Harrison RA, Nam JY, Weathers SP, DeMonte F. Intracranial dural, calvarial, and skull base metastases. Handb Clin Neurol 2018; 149:205-225

5 Michael CB, Gokaslan ZL, DeMonte F, McCutcheon IE, Sawaya R, Lang FF. Surgical resection of calvarial metastases overlying dural sinuses. Neurosurgery 2001;48(04):745-754, discussion 754-755

6 Ozgiray E, Perumal K, Cinar C, et al. Management of Calvarial Tumors: A Retrospective Analysis and Literature Review. Turk Neurosurg 2016;26(05):690-698

7 Stummer W, Stepp H, Möller G, Ehrhardt A, Leonhard M, Reulen HJ. Technical principles for protoporphyrin-IX-fluorescence guided microsurgical resection of malignant glioma tissue. Acta Neurochir (Wien) 1998;140(10):995-1000

8 Ferraro N, Barbarite E, Albert TR, et al. The role of 5-aminolevulinic acid in brain tumor surgery: a systematic review. Neurosurg Rev 2016;39(04):545-555

9 Kamp MA, Grosser P, Felsberg J, et al. 5-aminolevulinic acid (5ALA)-induced fluorescence in intracerebral metastases: a retrospective study. Acta Neurochir (Wien) 2012;154(02):223-228, discussion 228

10 Kamp MA, Munoz-Bendix C, Mijderwijk HJ, et al. Is 5-ALA fluorescence of cerebral metastases a prognostic factor for local recurrence and overall survival? J Neurooncol 2019;141(03): $547-553$ 
11 Knipps J, Fischer I, Neumann LM, et al. Quantification of PpIXfluorescence of cerebral metastases: a pilot study. Clin Exp Metastasis 2019;36(05):467-475

12 Millesi M, Kiesel B, Mischkulnig M, et al. Analysis of the surgical benefits of 5-ALA-induced fluorescence in intracranial meningiomas: experience in 204 meningiomas. J Neurosurg 2016;125 (06):1408-1419

13 Valdes PA, Millesi M, Widhalm G, Roberts DW. 5-aminolevulinic acid induced protoporphyrin IX (ALA-PpIX) fluorescence guidance in meningioma surgery. J Neurooncol 2019;141(03): 555-565

14 Hsieh CT, Sun JM, Tsai WC, et al. Skull metastasis from hepatocellular carcinoma. Management of Calvarial Tumors: A Retrospective Analysis and Literature Review. Acta Neurochir (Wien) 2007; 149(2):185-190

15 Zilberlicht A, Voldavsky E, Lavie O, Auslender R, Shai A. Prolonged survival in a patient with isolated skull recurrence of cervical carcinoma - Case report and review of the literature. Gynecol Oncol Rep 2014;11:20-22

16 Mitsuya K, Nakasu Y, Horiguchi S, et al. Metastatic skull tumors: MRI features and a new conventional classification. J Neurooncol 2011;104(01):239-245
17 Marbacher S, Klinger E, Schwyzer L, et al. Use of fluorescence to guide resection or biopsy of primary brain tumors and brain metastases. Neurosurg Focus 2014;36(02):E10. Doi: 10.3171/2013.12.FOCUS13464

18 Ramina R, Silva Júnior E, Constanzo F, Coelho Neto M. Indications of 5-Aminolevulinic Acid and Intraoperative MRI in Glioma Surgery: First Cases in Latin America in a Single Reference Center. Arq Bra Neurocir 2018;37(02):088-094

19 Ramina R, Da Silva Júnior E, Coelho Neto M, Ruschel L, Navarrette F. 5-Aminolevulinic Acid-Protoporphyrin IX Fluorescence-Guided Surgery for CNS Tumors. J Bras Neurocir 2018;27(01):13-19

20 Ruschel LG, Ramina R, da Silva EB Jr, Cavalcanti MS, Duarte JFS. 5Aminolevulinic acid fluorescence-guided surgery for spinal cord melanoma metastasis: a technical note. Acta Neurochir (Wien) 2018;160(10):1905-1908

21 Rustemi O, Della Puppa A. Hyperostosis and osteolysis in skull base meningiomas: are different nuances of 5-ALA fluorescence related to different invasion patterns? J Neurosurg Sci 2019;63 (04):484-485

22 Yang X, Palasuberniam P, Myers KA, Wang C, Chen B. Her2 oncogene transformation enhances 5-aminolevulinic acid-mediated protoporphyrin IX production and photodynamic therapy response. Oncotarget 2016;7(36):57798-57810 